Pamukkale University Journal of Social Sciences Institute

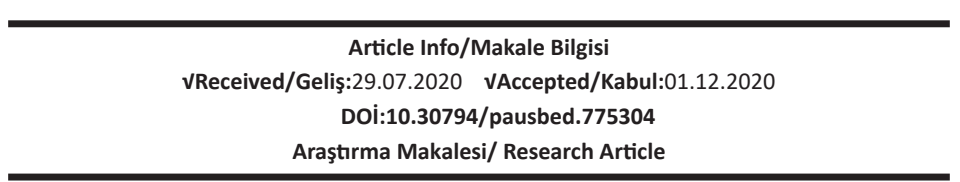

Öteyaka, I. (2021). "The Image of "Other" In Paul Kane's Wanderings of An Artist Among The Indians of North America " Pamukkale Üniversitesi Sosyal Bilimler Enstitüsü Dergisi, Sayı 45, Denizli, ss. 215-222.

\title{
THE IMAGE OF “OTHER” IN PAUL KANE'S WANDERINGS OF AN ARTIST AMONG THE INDIANS OF NORTH AMERICA
}

\section{Işı ÖTEYAKA*}

\section{Abstract}

Paul Kane's Wanderings of an Artist among the Indians of North America is a work in which Kane draws illustrative pictures of North American Indians and writes his experiences he had during the time span of a four year that he spent travelling among the Chippeways, Crees, Sioux and Blackfeet tribes of North American Indians. Though Kane's work reflects a European gaze on Indians which can be framed with the ideology of white supremacy, it is not grounded on hostile intentions for Indian people. Kane acknowledges Indian people's "wild nature", yet, contrary to the ideology of settler colonialism which is mainly based on the claim for land and gradual erasure of native agency, he mostly insists on the valuable aspects of native people's cultural life. Accordingly, this paper aims to show Paul Kane's awareness of this erasure, and his effort to catch the image of Indian as an Other that struggles to exist in his/her Self which will diminish in time.

Keywords: Paul Kane, Other, Settler colonialism.

\section{PAUL KANE'IN WANDERINGS OF AN ARTIST AMONG THE INDIANS OF NORTH AMERICA ESERINDE “ÖTEKI” IMAJI}

Öz

Paul Kane'in Wanderings of an Artist among the Indians of North America adlı eseri, Kane'in Kuzey Amerika yerlilerini tasvir eden resimler çizdiği ve Kuzey Amerika'nın Chippeway, Cree, Sioux ve Blackfeet kabilerleri arasında geçirdiği dört yıllık süre boyunca edindiği deneyimlerini yazdığı bir çalışmadır. Kane' in çalışması, yerliler üzerindeki beyaz ırkın üstünlüğü ideolojisiyle çerçevelenen Avrupa bakışını yansıtsa da, yerli halk için düşmanca niyetlere dayandırılmamaktadır. Kane, yerli halkın "vahşi doğa"sını kabul etmekle birlikte, esas olarak toprak talebine ve yerel hakimiyetin kademeli olarak silinmesi amacına dayanan yerleşimci sömürgecilik ideolojisinin aksine, çoğunlukla yerli halkın kültürel yaşamının değerli yönleri üzerinde ısrar etmektedir. Bu doğrultuda, bu çalışma Paul Kane'nin bu konudaki farkındalığını ve zamanla azalacak olan kendi Benliğinde var olmak için mücadele eden yerlinin Öteki olarak imajını yakalama çabasını göstermeyi amaçlamaktadır.

Anahtar kelimeler: Paul Kane, Öteki, Yerleşimci sömürgecilik.

*Assist. Prof. Dr., Foreign Language Education Department, Faculty of Education, Eskişehir Osmangazi University, ESKiŞEHIR

e-mail : ioteyaka@ogu.edu.tr (https://orcid.org/0000-0002-5792-5261) 


\section{Pamukkale Üniversitesi Sosyal Bilimler Enstitüsü Dergisi, Sayı 45, Temmuz 2021 I. Öteyaka}

\section{INTRODUCTION}

Colonization in North America, rooting back to 1500s with the settlements of Europeans on the East coast of the continent, took a form of settler colonialism the principles of which were based on the claim for land and practices of "dispossession of Indigenous peoples' territories and modes of traditional governance in exchange for delegated administrative powers to be exercised over relatively minuscule reserve lands" (Coulthard, 2014, p. 4). Indian people, despite being the indigenous ancestors of land and its possession, were gradually deprived of their authority and became an object of the white agency through "the logics of white supremacy" (Teves et al., 2015, p. 273). This "logics of white supremacy" acted on indigenous peoples by creating dichotomies that were institutionalized through discourses of history writing. Writing as an act of documentation was in the hands of white supremacy labelling indigenous peoples as "Other" to beware of. The concept of Other is basically grounded on the emphasis on the differences that the other culture/people/race do possess. In Difference and Pathology Sander Gilman notices the way people create the notion of difference by emphasising the determining role of the desire for a will-to-control. Gilman says that

"A rich web of signs and references for the idea of difference arises out of a society's communal sense of control over its world. No matter how this sense of control is articulated, whether as political power, social status, religious mission, or geographic or economic domination, it provides an appropriate vocabulary for the sense of difference. Difference is that which threatens order and control; it is the polar opposite to our group." (1985, pp. 20-21)

Any kind of fear of or anxiety in losing order and control leads to the practices of maintaining power and supremacy through a system of domination over the Other in order not to lose authority. In "The Economy of Manichean Allegory", Abdul R. JanMohamed points out the system of approach to the Other in colonialist literature by explaining the medium of relationship between the colonizer and the colonized, in other words the European and the Other, by focusing on the concepts of control and difference: "That world is therefore perceived as uncontrollable, chaotic, unattainable and ultimately evil. Motivated by his desire to conquer and dominate, the imperialist configures the colonial realm as a confrontation based on differences in race, language, social customs, cultural values, and modes of production" (1985, p. 64). Likewise, in Orientalism, Edward Said centers his discussion on an analysis of the concept of difference attributed to the Orient. He explains the concept of the Orient and Orientals, namely the East and its habitants that are "different" from the West, namely Europe, by indicating their condition as "stamped with an otherness -as all that is different, whether it be 'subject' or 'object'-" (1979, p. 97). Said places this otherness at the center of a dual vision reflected on the Orient: the Orient which "was overvalued for its pantheism, its spirituality, its stability, its longevity, its primitivity, and so forth" $(1979$, p. 150) was at the same time "underhumanized, antidemocratic, backward, barbaric, and so forth" (1979, p. 150). As Terry Goldie notes at that point, discourses of difference and otherness which are articulated for an unknown, alien not-self "could be applied to the indigenes of Australia, New Zealand, and Canada, as positive or negative attributes" (1989, p. 11). This application of positive or negative attributes to indigenous peoples is formed, adapted and adopted in accordance with "a sense of self [that] is rooted in a collective consciousness of "us' versus 'them"' (Morgan, 1999, p. 45). "Us" is always presented with positive qualities while "them" is always defined with the negative characteristics. As Colin G. Calloway states "They were routinely described as wild, savage, barbarous, primitive, lawless, warlike, treacherous, vengeful, lazy, dirty, poor, superstitious, and always in need of instruction and improvement $״(2008$, p. 3). They are described in negative terms and classified as the "Other" that is alien to the "Self" of this white supremacy. That alien Other became the object of the White man who wanted to convert the Other into a kind of Self. As Terry Goldie writes in Fear and Temptation "They are Other and Not-self but also must become self" $(1989$, p. 12). In this context, the aim is to change the Indian socially, culturally, and religiously: "Personal appearance, family relations, table manners - the smallest details of daily life had to be transformed if the Indian was going to take his place in the new society" (Francis, 1992, p. 52). Therefore, the Indian were destined to diminish and lose their culture and identity in order to exist in this new world. They were forced to exist in a very ironical situation: to 'die' in order to live. As stated by Patrick Wolfe: "Settler colonies were (are) premised on the elimination of native societies" (1999, p. 2). The white supremacy was 'killing' the image of Indian: Indian people had to forsake everything which makes them an Indian. This was the only way of the 'salvation' of native people. Francis states that "[...]the only way for Indians 


\section{Pamukkale Üniversitesi Sosyal Bilimler Enstitüsü Dergisi, Sayı 45, Temmuz 2021 I. Öteyaka}

to survive contact with White society was by acculturation. In order to save themselves as individuals, they must give up everything that defined them as people. This was the choice offered by the missionaries" (1992, p. 52). So the grim fate for Indian identity was 'to die' in order to live in this new society. Paul Kane's Wanderings of an Artist among the Indians of North America is a work that illustrates the characteristics of Indian people and their culture before that ultimate 'salvation'. Kane spent nearly four years travelling among the Chippeways, Crees, Sioux, Assiniboines and Blackfeet tribes of North American Indians. He painted illustrative pictures of the Indians and wrote his experiences in his Wanderings of an Artist among the Indians of North America. In his text, Kane approaches Indians of North America as worthy to be sketched and illustrated. Although he is aware of the "Other"ness of Indian people, he does not describe them fully in hostile terms or merely in primitive barbarism. He acknowledges their "wild nature", yet, contrary to the ideology of "the elimination of native societies", he mostly insists on the valuable aspects of native people's cultural life.

\section{Discussion}

In his Preface to Wanderings of an Artist among the Indians of North America, Paul Kane writes as follows:

"The principal object in my undertaking was to sketch pictures of the principal chiefs, and their original costumes, to illustrate their manners and customs, and to represent the scenery of an almost unknown country. These paintings, however, would necessarily require explanations and notes, and I accordingly kept a diary of my journey, as being the most easy and familiar form in which I could put such information as I might collect." (1859, p. viii)

As a painter, Kane was determined to sketch North American Indians, which was a deep interest since his boyhood, and his illustration of native people's manners, customs and the scenery of an almost unknown country records a last chance effort to document the characteristics of the Indians. In his text, Kane indicates that he "must travel far through the pathless forest to find them" (vii). From the very beginning, Indians seem to have already disappeared from those lands that the Great Spirit had given to them. This disappearance is one of the keystones of the logic of settler colonialism the aim of which is "to expropriate Indigenous territories and eliminate modes of production in order to replace Indigenous peoples with settlers who are discursively constituted as superior and thus more deserving over these contested lands and resources" (Saranillio, 2015, p. 284). Thus, ideology of colonial power was grounded on the possession of land by means of which native people were led to dispossession and disappearance: "If land is property, then migration, for whatever reason, relies on a displacement or disappearance of indigenous peoples" (Teves et al., 2015, p. 277). Kane's text not only marks this disappearance, but it is also "a written record [...] [of] the indigenous Other through the lens of discovery" (Witgen, 2012, p. 17). Nevertheless, this lens of discovery does not contribute to hostile intentions of colonial power. Through this lens, Kane becomes an agent introducing the "Other", the unknown to the public audience, and making it less ambiguous. Kane's contact with indigenous peoples is not through a military interaction but, through a communication, albeit a non-linguistic one, which relies on mutual respect together with a kind of fear that is led by negotiation:

"The multiple kingdoms reached across the oceans, where identities of both British and indigenes were subject to constant re-negotiation. This process was more than a simple encounter between two stable, fixed identities, for both were fractured and various, changing over time and space in constant interplay and mutual redefinition. It should also be stressed that these identities were defined and took on meaning only in relation to each other. It was not merely that imperial power, springing from many sources, classified, defined and sought to dominate indigenous peoples, but that equally the identities of Britons themselves took shape in relation to the colonized 'other'." (Daunton \& Halpern, 1999, p. 6)

Kane, not subscribing to an imaginary representation of indigenous peoples in which "to say 'native' is automatically to say 'evil' (JanMohamed, 1985, p. 65), is aware of the importance of his contribution to the records of history, and declares that what he has done is "also an intrinsic value to the historian" (viii). It is significant to note that this intrinsic value and its operations on the perception of Indian people is set by a European consciousness represented by Kane. Kane, being in possession of the faculty of writing, recording, and depicting, has power of moulding Indian identity through a European eye. As Jeffers Lennox indicates in his 


\section{Pamukkale Üniversitesi Sosyal Bilimler Enstitüsü Dergisi, Sayı 45, Temmuz 2021 I. Öteyaka}

analysis of territorial interactions between Europeans and Indians: "Recording history (or, in this case, depicting geography) was a form of power over what is remembered and how the story is told" (2017, p. 9).

Michael Witgen emphasizes the aim and scope of imperial gaze which not only scrutinizes the Indian and his/ her surroundings but also exerts power on the lives of the Indians. Witgen states that

Tales of discovery were meant to convey the power of Europe in the form of an imperial gaze that reached into the unknown territories of the New World, and made this space and its peoples comprehensible to outsiders. But they were also meant to illuminate the superiority of European ways of being-governance, sacred practices, means and methods of economic production, material goods, and so on - and the corresponding inferiority of New World peoples whose advancement (civilization) depended on acquisition of the artifacts and knowledge of their discoverers. Because of this bias, these documents also serve as cautionary tales about the ways in which both individual travelers and traders, and the empires they served claimed to exercise power. (2012, p. 55)

The power of Kane's imperial gaze is both to illuminate the superiority of European and at the same time to capture a sketch of the Indian in his/her native notions of life without deeming them hostile. Accordingly, Kane attributes to Indians mostly the characteristics of a noble savage (Francis, 1992): his text is mainly about how Indians are very well adapted to nature, their faithfulness, their practical skills in hunting, healing and medicine, their innate wisdom, and their friendly generosity during his wanderings. In "Settler Governmentality and Racializing Surveillance in Canada's North-West", Jeffrey Monaghan deals with the Canadian governmental colonial surveillance practices on the indigenous peoples "to eliminate indigenous opposition to settler colonial expansion in the North-West" (2013, p. 489). Monaghan points out the imperial gaze and its potential in surveillance by indicating that

surveillance was necessary for identifying indigenous peoples and sorting them based on their adoption of, or resistance to, practices of European liberalism imposed by the Canadian settler state. As settler colonialism was seen as the civilized progression of European reason, colonial surveillance practices necessitated a vigilant gaze towards traces of indigeneity that marked deviant behaviour from, or dangerous threats towards, the expansion of settler governance. (2013, p. 489)

Although Kane's depiction of Indians via his sketches and notes delivered through his diary may, as a typical example of surveillance practices, exemplify a close observation of the doings of indigenous peoples, his aim in these sketches does not match with the intentions of surveillance practices that target to detect threats in settler governance, which he points out in his preface as follows:

The illustrations-executed from my sketches, or finished paintings, for the purpose of illustrating the present work - constitute only a few specimens of the different classes of subjects which engaged my pencil during a sojourn of near four years among the Indians of the North-west. In that period I executed numerous portraits of chiefs, warriors, and medicine-men of the different tribes among whom I sojourned, and also of their wives and daughters. The Indian fishing and hunting scenes, games, dances, and other characteristic customs, also occupied my pencil; while I was not forgetful of the interest which justly attaches to the scenery of a new and unexplored country, and especially to such parts. (1859, p. ix)

Kane's observation serves to illustrate how European Self creates the image of Other through parameters of land ownership, economy, language and manners. Kane's first visit is to the Indian village of Saugeen. His description frames Indians mostly in economic bounds with the Provincial Government. They are represented as; not having any interest in cultivation of the land and as a result not having a stable earning, being in need of money which leads to the sale of some portion of their land to the Government. Indians are the original owners of land but now they are deterritorialized. As stated by Teves et al. "If land is property, then migration, for whatever reason, relies on a displacement or disappearance of indigenous peoples" (2015, p. 277). Despite losing their territory and becoming scattered in different tribes, there is a sense of oneness and unity among the Indians as Kane emphasizes "[...] they speak the same language; their medicine dances, called Matayway, and their feasts are in every respect the same, identifying them as one and the same people, although scattered so widely apart" 


\section{Pamukkale Üniversitesi Sosyal Bilimler Enstitüsü Dergisi, Sayı 45, Temmuz 2021 I. Öteyaka}

$(1859$, p. 4). Indeed, Kane projects his idea of nation or nationality on the Indian people. Being the one and the same, Indians are presented in a positive way, albeit lower in quality in certain respects. Like other colonial discourses which classify Indians as filthy people, Kane's discourse, too, marks their poor quality of cleanliness: "The filth, stench, and vermin make them almost intolerable to a white man; but Indians are invariably dirty, and it must be something very terrible indeed which will induce them to take half an hour's trouble in moving their lodge" (1859, p. 8). Kane explicitly draws the distinction between the Indian and the white man: Indians are dirty and their dirtiness is not something disturbing among their community whereas a clean white man cannot endure the filthy and messy place which is entirely alien to him. However, he does not adopt a tone of hostility. He merely takes note of the difference he observes; and he represents what he sees and does not use a language that condemns the Indians intemperately or angrily.

While depicting Indians he met during his travels, Kane touches upon the Government's protection policy, a policy which portrays the Government as taking care of the Indians: "The village consists of forty or fifty loghouses built by the Provincial Government for the Indians. There is a mission, with a church and pastor, an Indian agent, a doctor, and a blacksmith, all paid by the Government" (1859, p. 10). He thus depicts the Government like a caring father for the Indians. In spite of this care, Indians are always in need of money. Kane states that the Indians, in an anxious suspense, are always waiting desperately for the money from the Government in return for the lands that are sold. This father-figure image is sustained in the depiction of Hudson's Bay Company as well. It is presented like a paternal power that provides advantages of civilisation and helps Indians keep their identity intact: "the Indians are fast declining in character, numbers, and wealth, whilst those in contact with the Hudson's Bay Company maintain their numbers, retain native characteristics unimpaired, and in some degree share in the advantages which civilisation places within their reach." (Kane, 1859, p. 98). Indians are mainly depicted as having agency in hunting, healing, and fighting. Nevertheless, their agency in maintaining moral conduct is presented as being maintained by civilization which is represented by Hudson's Bay Company:

"The half-breeds are much inclined to grumbling, and although the Company treat them with great liberality, they still ask almost for impossibilities; indeed, as far as the Company is concerned, I cannot conceive a more just and strict course than that which they pursue in the conduct of the whole of their immense traffic. In times of scarcity they help all around them, in sickness they furnish them with medicines, and even try to act as mediators between hostile bands of Indians. No drunkenness or debauchery is seen around their posts, and so strict is their prohibition of liquor, that even their officers can only procure a small allowance, which is given as part of their annual outfit on voyages." (1859, p. 96-97)

When Kane is in Canadian territory, he visits a number of forts one of which is Fort Garry in the Hudson's Bay territory which he describes as having "a stone wall with bastions mounted with cannon, inclosing large storehouses and handsome residences for the gentlemen of the establishment. Its strength is such that it has nothing to fear from the surrounding half-breeds or Indians" $(1859$, p. 96). Fort represents the white supremacy and power with its well-built structure, and the basic distinction between the white men and the Indians is clearly drawn: white men are the true gentlemen who are special while the Indians are inclined to savagery which is feared. Moreover, the White man, represented by Hudson's Bay Company, is represented again like a caring father figure whose interest is

"to improve the Indians and encourage them to industry, according to their own native habits in hunting and the chase, even with a view to their own profit, it is as obviously the interest of small companies and private adventurers to draw as much wealth as they possibly can from the country in the shortest possible time, although in doing so the very source from which the wealth springs should be destroyed." (1859, p. 97)

Kane values the Hudson's Bay Company's policy which "had no motive to encourage the Indians to abandon their nomadic life for the civilized habits of a settled people, or even to interpose in the wars which varied the monotony of the Indians' wild hunter-life, they had so thoroughly won the confidence of the natives, that tribes at open enmity with each other were ready to repose equal confidence in the Hudson Bay factors" (Wilson, 1892, p. 259). 
While Hudson's Bay Company represents the white authority that holds the power of control and regulation, Indians are typified with their tribal and warrior characteristics alongside their emotional traits. Kane presents Indians' warlike traits both as a part of their culture and as one of the reasons that cause their depopulation:

"These wars are kept up with unremitting perseverance from year to year; and were they as destructive in proportion to the numbers engaged as the wars of civilised nations, the continent would soon be depopulated of the whole Indian race; but, luckily, Indians are satisfied with small victories, and a few scalps and horses taken from the enemy are quite sufficient to entitle the warriors to return to their friends in triumph and glory" (Kane, 114-115).

Although Indians are known for their passionate warrior characteristics, Kane' text draws more attention to their emotional traits. Kane depicts a romanticized image of an Indian warrior who gave up his warlike pursuits after losing his beloved before their marriage. He says that this Indian man "was so much grieved" upon the loss of "his warmest love" and "throwing up the tomahawk to the Great Spirit, that it might be employed only as an instrument of justice, he took in its stead the rattle of the medicine-man; nor did he ever after act inconsistently with his altered character" $(1859$, p.23). This human image clashes quite explicitly with the generally accepted savage, brutal image of the Indian people. Moreover, Kane presents a positive image of the Indians by emphasising the Indians' adherence to their promises. He mentions an intelligent Indian named Sigennok who quitted drinking after getting bound by an English captain because of the danger of his drunken state. Feeling treated with indignity, Sigennok promises never to drink again in order for the captain to release him, and it is said that he "had never been known to violate the promise then made" (1859, p. 13).

Drinking and gambling are the other characteristics of the Indian people in Kane's text: "Liquor, whenever they can obtain it, is their chief bane, and lays them more open to the fraudulent schemes of their despoilers" says Kane $(1859$, p. 35$)$. This creates a paradoxical situation, because, though prohibited by the law, it is the white man who sells "spirits" to the Indians, so it is the white man who turns the Indian into "one of the most dangerous animals" (1859, p. 35). Similarly, Indians' addiction to gambling is a part of the depiction of the tribes. The chief of Chualpays is aware of the negative behaviour brought out by gambling such as cheating and dishonesty, and he opposes it "but still the passion for gambling continues, and an instance occurred during my stay here of a young man committing suicide by shooting himself, having lost everything he possessed by indulging in this habit" (1859, pp. 309-310).

Despite the fact that Kane mentions the Indians as vengeful warriors when exposed to grievance, or like the most dangerous animals living in dirt, he always expresses the kindness and attention he received without any hostile intentions from the Indians, especially from the Sioux which was considered to be the most savage tribe. Kane also talks about the Weendigo tribe who are believed to be cannibals, but he informs his readers that it is a superstitious belief among the Indians and he, as a close observer, adds that "I do not think that any Indian, at least none that I have ever seen, would eat his fellow creature, except under the influence of starvation; nor do I think that there is any tribe of Indians on the North American continent to whom the word 'cannibal' can be properly applied" (1859, p. 61). He acknowledges their uncivilized behavior but he mostly values Indians' humane qualities which any white man can also possess. Moreover, the world of Indian people is strongly based on a belief system which is set by spiritual values and their connection to nature. Indian people conform to the regulations of the Great Spirit whom they cringe before fearing that they would be punished and cursed by it if they do not conform to the regulations of their belief system. This fear makes them easily affected and discouraged like a child.

Being a close witness to Indian culture, Kane depicts what he sees directly without coloring his depiction with any prejudices. His depictions of Indians, whether in their physicality or spirituality, are distinct from the ideology of "settler governmentality [which] treats expressions of traditional indigeneity as forms of abnormality because they represent a barrier to the creation of a new (white) social order" (Monaghan, 2013, p. 493). Kane values traditional indigeneity symbolized by and reflected in the objects such as medicine-pipe-stems, furs, clothes, and in the customs of dancing, singing, and calling on the Great Spirit. Indians' spirituality and their connection with nature are not rejected or denigrated by Kane. Rather, those traits are regarded as a consciousness, a "Self" 
facing extinction that he aspires to sketch. One of his depictions describes the chief Saw-se-a, the head chief of the Cowitchins, who was a great warrior in his youth. Kane, without underestimating the role of a chief as a ruler, foregrounds the qualities he possesses such as courage, bravery, wisdom and faithfulness. The Chief is a warrior protecting his community and supporting them with wealth he has accumulated. That the chief distributes his wealth among his people and neighbouring chiefs is not only a sign of faith between him and his people but also a token of his fame and pride among the people of his tribe: "The object in thus giving his treasures away is to add to his own importance in the eyes of others, his own people often boasting of how much their chief had given away, and exhibiting with pride such things as they had received themselves from him" (Kane, 1859, p. 221). Chiefs are also portrayed within a generosity so as to honour someone helpful to him by giving his name to that person: "It is not an uncommon thing for a chief, when he wishes to pay you a very high compliment, to give and call you by his own name, and adopt some other for himself" (1859, p. 205).

Despite the mutual interaction based on negotiation between the Indians and the white society, there is a certain border that divides both sides and positions each as the "Other" in relation to one another. Kane mentions one of the Christianized Indians who claims to have visited

"the white man's heaven [...] where they had everything that the white man loves and longs for; but the Indian could not share their joy and pleasure, for all was strange to him, and he met none of the spirits of his ancestors, and there was none to welcome him, no hunting nor fishing, nor any of those joys in which he used to delight, and his spirit grew sad." (1859, pp. 394-395)

White man's heaven does not create a sense of home in the Indian psychology, likewise, Indian territory is a wild and alien place to the white community. Being in a position of "Other" to each other, both sides maintain their sense of Self through customs and manners. In this maintenance, Indian self is not depicted within hostile intentions.

\section{CONCLUSION}

Paul Kane represents Indian people living in harmony with nature and Great Spirit. Although he expresses his awareness of the "savage, wild" life of the Indians, he respects their traditional cultural manners. Indians are described as skilful, proud, practical, spiritual and friendly figures. With their hunting skills, rituals held in the name of Great Spirit, and healing practices, Indians draw a mysterious, spiritual image that is unknown to the artist. What Kane tried to do is to catch that image which was going to disappear in time. Representing the Indians in a less negative way contrary to the generally accepted merely brutal Indian image, Kane portrays the image of the "Other" who struggled to exist in his/her own "Self". Kane's interaction with Indian peoples portrays of a symbiosis between Western and indigenous cultures. Though Indians seem uncontaminated cultural isolates maintaining a sense of self, there is an interaction which assuredly will bring about cultural interchange. It would be useful to conduct further studies exploring how this interchange, despite social and cultural distance, leads to the acculturation of Indian people.

\section{REFERENCES}

Calloway, C. G. (2008). White People, Indians, and Highlanders: Tribal Peoples and Colonial Encounters in Scotland and America. Oxford University Press.

Coulthard, G. S. (2014). Red Skin, White Masks: Rejecting the Colonial Politics of Recognition. University of Minnesota Press.

Francis, D. (1992). The Imaginary Indian : The Image of the Indian in Canadian Culture. Arsenal Pulp Press.

Gilman, S. (1985). Difference and Pathology. Cornell University Press.

Goldie, T. (1989). Fear and Temptation: The Image of the Indigene in Canadian, Australian, and New Zealand Literatures. McGill-Queen's University Press.

JanMohamed, A. R. (1985). The Economy of Manichean Allegory: The Function of Racial Difference in Colonialist Literature. Critical Inquiry, 12(1), 59-87. http://www.jstor.org/stable/1343462 
Kane, P. (1859). Wanderings of an Artist among the Indians of North America: From Canada to Vancouver's Island and Oregon through the Hudson's Bay Company's Territory and Back Again. Spottiswoode and Co.

Lennox, J. (2017). Homelands and Empires: Indigenous Spaces, Imperial Fictions, and Competition for Territory in Northeastern North America, 1690-1763. University of Toronto Press.

Monaghan, J. (2013). Settler Governmentality and Racializing Surveillance in Canada's North-West. The Canadian Journal of Sociology / Cahiers canadiens de sociologie, 38(4), 487-508. www.jstor.org/stable/ canajsocicahican.38.4.487

Morgan, P. D. (1999). Encounters between British and "indigenous". In M. Daunton \& R. Halpern (Eds.), Empire and Others: British Encounters with Indigenous Peoples, 1600-1850. University of Pennsylvania Press.

Said, E. W. (1979). Orientalism. Vintage Books.

Saranillio, D. I. (2015). Settler Colonialism. In S. N. Teves, A. Smith, \& M. H. Raheja (Eds.), Native Studies Key Words. The University of Arizona Press.

Teves, S. N., Smith, A., \& Raheja, M. (2015). Colonialism. In S. N. Teves, A. Smith, \& M. Raheja (Eds.), Native Studies Keywords. University of Arizona Press.

Witgen, M. (2012). PROLOGUE. The Long Invisibility of the Native New World. In An Infinity of Nations (pp. 1-22). University of Pennsylvania Press. www.jstor.org/stable/j.ctt3fj1jp.3

Wolfe, P. (1999). Settle Colonialism and the Transformation of Anthropology: The Politics and Poetics of an Ethnographic Event. Cassell.

\section{Beyan ve Açıklamalar (Disclosure Statements)}

1. Bu çalışmanın yazarları, araştırma ve yayın etiği ilkelerine uyduklarını kabul etmektedirler (The authors of this article confirm that their work complies with the principles of research and publication ethics).

2. Yazarlar tarafından herhangi bir çıkar çatışması beyan edilmemiştir (No potential conflict of interest was reported by the authors).

3. Bu çalışma, intihal tarama programı kullanılarak intihal taramasından geçirilmiştir (This article was screened for potential plagiarism using a plagiarism screening program).

4. Bu makale için etik kurul izni gerekmemektedir (Ethics committee permission is not required for this article). 